\title{
Dysregulation of the homeobox transcription factor gene HOXB /3: role in prostate cancer
}

\author{
Brennan Decker ${ }^{1,2}$ \\ Elaine A Ostrander ${ }^{1}$ \\ 'Cancer Genetics and Comparative \\ Genomics Branch, National Human \\ Genome Research Institute, National \\ Institutes of Health, Bethesda, MD, \\ USA; ${ }^{2}$ Centre for Cancer Genetic \\ Epidemiology, Department of Public \\ Health and Primary Care, School \\ of Clinical Medicine, University of \\ Cambridge, Cambridge, UK
}

This article was published in the following Dove Press journal:

Pharmacogenomics and Personalized Medicine

5 August 2014

Number of times this article has been viewed

\begin{abstract}
Prostate cancer (PC) is the most common noncutaneous cancer in men, and epidemiological studies suggest that about $40 \%$ of PC risk is heritable. Linkage analyses in hereditary PC families have identified multiple putative loci. However, until recently, identification of specific risk alleles has proven elusive. Cooney et al used linkage mapping and segregation analysis to identify a putative risk locus on chromosome 17q21-22. In search of causative variant(s) in genes from the candidate region, a novel, potentially deleterious G84E substitution in homeobox transcription factor gene $H O X B 13$ was observed in multiple hereditary PC families. In follow-up testing, the G84E allele was enriched in cases, especially those with an early diagnosis or positive family history of disease. This finding was replicated by others, confirming $H O X B 13$ as a PC risk gene. The HOXB13 protein plays diverse biological roles in embryonic development and terminally differentiated tissue. In tumor cell lines, HOXB13 participates in a number of biological functions, including coactivation and localization of the androgen receptor and FOXA1. However, no consensus role has emerged and many questions remain. All HOXB13 variants with a proposed role in PC risk are predicted to damage the protein and lie in domains that are highly conserved across species. The G84E variant has the strongest epidemiological support and lies in a highly conserved MEIS protein-binding domain, which binds cofactors required for activation. On the basis of epidemiological and biological data, the G84E variant likely modulates the interaction between the HOXB13 protein and the androgen receptor, as well as affecting FOXA1-mediated transcriptional programming. However, further studies of the mutated protein are required to clarify the mechanisms by which this translates into PC risk.
\end{abstract}

Keywords: prostate cancer risk, HOXB13

\section{Introduction}

Prostate cancer (PC) is the most common noncutaneous cancer in men in the Western world, with about 240,000 new cases diagnosed in $2011 .{ }^{1}$ Twin studies, ${ }^{2-4}$ segregation analysis, ${ }^{5-11}$ and linkage of high-risk or hereditary families all suggest that there are hereditary components to the disease. ${ }^{12-18}$ However, replication of linkage results has proven difficult, and few high-risk alleles have been conclusively identified. Genome-wide association studies have identified more than 75 common alleles that are also associated with increased PC risk, and although many of these have been validated, each is predicted to make a small contribution to disease risk. ${ }^{19-25}$ Finally, family-based association studies have contributed additional validated loci. ${ }^{26,27}$

Despite this enormous amount of work, the greatest challenge remains: how can we accurately and efficiently identify the subset of men who will go on to die of

Correspondence: Elaine A Ostrander

Cancer Genetics and Comparative

Genomics Branch, National Human

Genome Research Institute, National Institutes of Health, 50 South

Dr Building 50, Room 535I,

Bethesda, MD, 20892 USA

$\mathrm{Tel}+\mathrm{I} 30 \mathrm{I} 5945284$

$\mathrm{Fax}+$ I 30I 4800472

Email eostrand@mail.nih.gov
Pharmacogenomics and Personalized Medicine 20|4:7 |93-20| 
metastatic disease versus those with slow-growing indolent PC? While a variety of approaches have been tested, including linkage analysis of high-risk families using various measures of aggressiveness as the phenotype $\mathrm{e}^{28-32}$ and scans based on Gleason grade among family members, ${ }^{33-35}$ few replicated loci have been identified.

Thus, much current research in the field is focused on 1) identifying genetic factors that predispose to any level of disease risk; 2) understanding the tumor biology and genetic factors that contribute to tumor aggressiveness and metastatic progression; and 3) identifying a panel of genetic markers that predict aggressive forms of PC. In 2012, significant progress was made on all of these questions with the discovery of mutations in homeobox transcription factor gene $H O X B 13$ that were associated with both familial and population-based risk. We summarize the state of the field with regard to $H O X B 13$ in the following review.

\section{Initial findings}

$H O X B 13$ was identified as a risk factor for PC following a series of studies led by Ewing et al. ${ }^{36}$ These investigators followed up on their initial findings of linkage in high-risk families at chromosome 17q21-23. ${ }^{37,38}$ The initial linkage peak was identified in a scan of 175 hereditary pedigrees and was replicated by the International Consortium for Prostate Cancer Genetics, a large collaborative group with more than 2,000 hereditary PC families. ${ }^{39,40}$ Fine mapping of the region narrowed the focus to chromosome 17q21-22, a region with more than 200 genes in the minimal recombination region. ${ }^{41}$ With this smaller region identified, the group evaluated the coding sequence of 202 candidate genes in search of potential PC susceptibility alleles or genes. ${ }^{36}$ Targeted sequencing of the youngest cases in families with evidence of linkage focused attention on the $H O X B 13$ gene, as four of the sequenced families harbored a novel (G84E) substitution that was predicted to be deleterious. In follow-up genotyping, all 18 cases in these four families were observed to carry the mutation. Analysis of a population of 5,083 unrelated individuals with PC suggested a frequency of about $1.4 \%$, compared to $0.1 \%$ in 1,401 healthy male controls from the general population. The carrier rate was highest in younger cases who reported a family history of PC (3.1\%). Thus, cases from the general population, as well as cases from families with history of PC, were significantly enriched for the G84E variant, with all $P<0.001$. Interestingly, while the G84E mutation appeared to be the most common risk variant in this initial study, two additional variants, R229G and G216C, were found in African American families.
Three individuals in one family segregated a c.685 C>G transversion, which encodes the R229G variant at a highly conserved position. Additional rare variants were found in other families, but G84E was most frequent and most strongly implicated in PC.

\section{HOXB I 3 findings replicated}

The strength of the epidemiological findings and intriguing biological role of $H O X B 13$ generated great interest among PC researchers. Many groups who were underwhelmed by earlier reports of $\mathrm{PC}$ candidate risk genes mobilized to replicate these findings. The story was compelling for several reasons. First, the chromosome 17 region that harbors the gene was initially selected for intense study because multiple studies of high-risk PC families had already uncovered evidence for genetic linkage at the locus. ${ }^{41,42}$ Second, in the data presented by Ewing et al, ${ }^{36}$ multiple large families faithfully segregated the same mutation, which strengthened the result. The finding was upheld in multiple subsequent studies, and several are described below, as well as in Table 1.

Stott-Miller et $\mathrm{al}^{43}$ reported results from a populationbased, case-control study of men in western Washington State, where they observed the G84E mutation in $1.3 \%$ of cases versus $0.4 \%$ of controls, which represents a 3.3 -fold higher relative risk in carriers versus noncarriers. The initial finding of a stronger association in the setting of positive family history was also replicated. Furthermore, risk estimates for the variant were also higher among men with higher versus lower Gleason score at diagnosis (odds ratio $[\mathrm{OR}]=4.13$, $95 \%$ confidence interval $[\mathrm{CI}]=1.38-12.38$ versus $\mathrm{OR}=2.71$, $95 \% \mathrm{CI}=0.88-8.30$ ) and advanced versus prostate-confined disease. ${ }^{43}$ While these differences were not statistically significant, they may suggest that $H O X B 13$ G84E is a marker for disease aggressiveness. The same year, Witte et $\mathrm{al}^{44}$ evaluated two cohorts, a family-based study of brothers and a casecontrol study of 2,665 men with more aggressive disease. In their study, the mutation was detected in $1.47 \%$ of cases, in stark contrast with $0.34 \%$ among unaffected brothers in the family-based analysis, and there was a complete absence of the variant in controls from the case-control arm. ${ }^{44}$ Again, the mutation was more common among men with early-onset disease or a positive family history. ${ }^{44}$

Not surprisingly, given the association with family history, the result has also replicated in family studies. One of the first such studies was an examination of familial PC from Vanderbilt University. ${ }^{45}$ These investigators genotyped 930 controls without a personal or family history of PC and 928 familial cases, and observed the mutation in 16 of 
Table I HOXB 13 risk allele studies cited in this review

\begin{tabular}{|c|c|c|c|c|c|c|c|c|}
\hline Study & Study design & Population & $\begin{array}{l}\text { Number } \\
\text { of subjects }\end{array}$ & $\begin{array}{l}\text { Case carrier } \\
\text { frequency }\end{array}$ & $\begin{array}{l}\text { Risk } \\
\text { estimate }\end{array}$ & $95 \% \mathrm{Cl}$ & $P$-value & Comments \\
\hline Ewing et $\mathrm{a}^{36}$ & $\begin{array}{l}\text { Population-based } \\
\text { case-control }\end{array}$ & US & 6,484 & $1.40 \%$ & $O R=20.1$ & $3.5-803.3$ & $<0.001$ & $\begin{array}{l}\text { Association with family } \\
\text { history, early diagnosis }\end{array}$ \\
\hline $\begin{array}{l}\text { Stott-Miller } \\
\text { et al }{ }^{43}\end{array}$ & $\begin{array}{l}\text { Population-based } \\
\text { case-control }\end{array}$ & US & 2,569 & $1.30 \%$ & $\mathrm{RR}=3.3$ & $1.2-9.0$ & & $\begin{array}{l}\text { Association with family } \\
\text { history }\end{array}$ \\
\hline Lin et $a^{51}$ & $\begin{array}{l}\text { Population-based } \\
\text { case-control }\end{array}$ & $\begin{array}{l}\text { People's } \\
\text { Republic of } \\
\text { China }\end{array}$ & 2,111 & $0.35 \%$ & & & 0.027 & $\begin{array}{l}\text { G84E allele not } \\
\text { observed; alternate risk } \\
\text { variant proposed for } \\
\text { Chinese population }\end{array}$ \\
\hline $\begin{array}{l}\text { Karlsson } \\
\text { et a }\left.\right|^{48}\end{array}$ & $\begin{array}{l}\text { Population-based } \\
\text { case-control }\end{array}$ & Sweden & 9,696 & $4.30 \%-4.60 \%$ & $R R=3.4$ & $2.2-5.4$ & $<0.001$ & $\begin{array}{l}\text { Control population had } \\
\text { a carrier rate of } 1.3 \%\end{array}$ \\
\hline Witte ${ }^{44}$ & $\begin{array}{l}\text { Aggressive disease } \\
\text { case-control }\end{array}$ & US & 1,540 & $0.81 \%$ & $\mathrm{OR}=4.8^{*}$ & & 0.01 & $\begin{array}{l}\text { Association with early } \\
\text { diagnosis }\end{array}$ \\
\hline Ewing ${ }^{36}$ & $\begin{array}{l}\text { Family-based } \\
\text { case-control }\end{array}$ & US & I,486 & $4.70 \%$ & $\mathrm{OR}=68 . \mathrm{I}$ & & $<0.001$ & \\
\hline Witte ${ }^{44}$ & $\begin{array}{l}\text { Family-based } \\
\text { case-control }\end{array}$ & US & $\mathrm{I}, \mathrm{I} 34$ & $1.89 \%$ & $\mathrm{OR}=4.8^{*}$ & & 0.01 & $\begin{array}{l}\text { Association with early } \\
\text { diagnosis }\end{array}$ \\
\hline Breyer et $\mathrm{al}^{45}$ & $\begin{array}{l}\text { Family-based } \\
\text { case-control }\end{array}$ & US & 1,858 & $1.90 \%$ & $\mathrm{OR}=7.9$ & $1.8-34.5$ & 0.0062 & $\begin{array}{l}\text { Association with family } \\
\text { history }\end{array}$ \\
\hline$X^{46}$ & $\begin{array}{l}\text { Family-based } \\
\text { case-control }\end{array}$ & Multiple & 2,443 families & $4.60 \%$ of families & $\mathrm{OR}=4.4$ & $2.6-7.5$ & $<0.001$ & $\begin{array}{l}51 \% \text { of cases from } \\
\text { carrier families } \\
\text { harbored risk allele }\end{array}$ \\
\hline $\begin{array}{l}\text { Schroeck } \\
\text { et al }{ }^{49}\end{array}$ & $\begin{array}{l}\text { Biopsied subjects } \\
\text { cohort }\end{array}$ & US & 948 & $0.42 \%$ & & & & $\begin{array}{l}\text { G84E variant has } \\
\text { low utility at time of } \\
\text { diagnostic biopsy }\end{array}$ \\
\hline Chen et $\mathrm{al}^{50}$ & Cohort & Multiple & 3,508 & $0.99 \%$ & $\mathrm{RR}=2.5$ & $1.5-4.1$ & 0.01 & $\begin{array}{l}\text { Allele detected only in } \\
\text { Caucasians }\end{array}$ \\
\hline Maclnnis ${ }^{47}$ & $\begin{array}{l}\text { Population-based } \\
\text { families }\end{array}$ & Australia & $\mathrm{I}, 384$ & $1.40 \%$ & $R R=16.4$ & $2.5-107.2$ & & $\begin{array}{l}\text { Estimated penetrance } \\
\text { of } 60 \% \text { by age } 80 \text { years }\end{array}$ \\
\hline
\end{tabular}

Note: *OR for both sibling and case-control arms.

Abbreviations: $\mathrm{Cl}$, confidence interval; $\mathrm{OR}$, odds ratio; $\mathrm{RR}$, relative risk.

the familial cases versus only two controls (OR $=7.9,95 \%$ $\mathrm{CI}=1.8-34.5$ ). The carrier rate was $1.9 \%$ in all probands, but it went up $30 \%$ in cases who had $\geq 3$ affected family members. ${ }^{45}$ The primary result was also confirmed in the much larger International Consortium for Prostate Cancer Genetics study in which investigators genotyped the G84E variant and 14 other single-nucleotide polymorphisms (SNPs) in 2,443 families. ${ }^{46}$ They showed that at least one mutation carrier was present in 112 families (4.6\%) and that within the carrier families, the G84E variant was more common among men with disease than among those without. The mutation was in the same haplotype in the majority ( $95 \%$ ) of carriers, strongly suggesting a founder effect. Overall, these findings suggest that nearly $5 \%$ of cases from high-risk families carry the G84E mutation.

Several reports have addressed penetrance of the allele in addition to risk. An Australian study found that 19 of 1,384 probands $(1.4 \%)$ carried the G84E mutation. Six of those men had a family history of PC. The age-specific incidence for carriers in Australia was estimated to be 16.4-fold higher $(95 \%$ CI $=2.5-107.2)$ than expected levels based on birth year. This study also estimated birth year-specific cumulative risk for carriers and found that penetrance was $60 \%$ by age 80 , which is higher than other estimates. ${ }^{47}$ By comparison, Karlsson et $\mathrm{al}^{48}$ examined 5,003 cases and 4,693 controls from Sweden and showed that the G84E mutation was present in $1.3 \%$ of population controls and $4.6 \%$ of cases, providing a strong association with $\mathrm{PC}$ risk $(\mathrm{OR}=3.4$, $95 \% \mathrm{CI}=2.2-5.4$ ). Again, the strongest associations were for those with early-onset disease or a positive family history. Among cases aged 35-55 years, the carrier frequency was $10.3 \%(\mathrm{OR}=8.6,95 \% \mathrm{CI}=5.1-14.0)$. In this situation, the investigators estimated the collective risk of G84E carriers to be $33 \%$ by 80 years of age, compared to the $12 \%$ risk that was observed in this population among noncarriers. ${ }^{48}$

The carrier frequency for men undergoing diagnostic biopsy is much lower than that reported in case-control or PC family-based studies. For instance, Schroeck et al ${ }^{49}$ observed that among 938 biopsied men, the prevalence of the G84E mutation was $0.42 \%$. Three of the four carriers had PC. None of 301 men with a positive family history and one of 226 men 
diagnosed before age 55 were carriers, yielding an overall prevalence of $0.44 \%$ and raising questions about the utility of clinical testing for this variant in this setting.

\section{HOXB / 3 within and across populations}

It is clear that the frequency of the G84E allele varies significantly between populations. In a multinational study of 2,508 subjects from the REDUCE (Reduction by Dutasteride of Prostate Cancer Events) trial, the authors reported that the G84E mutation frequency was $1.06 \%$ in biopsy-negative men from Northern Europe, followed by $0.60 \%$ and $0.31 \%$ in Europe and North America, respectively. ${ }^{50}$ No carriers were observed among populations from a variety of other regions, including southern and eastern Europe, South Africa, Latin America, and Australia. ${ }^{50}$ In Caucasians alone, the mutation frequency was $0.99 \%$ in biopsy-positive men versus $0.24 \%$ in controls. All mutation carriers had a common haplotype that was once again indicative of a founder effect. ${ }^{50}$

Because the G84E risk allele is entirely absent in some populations, some have suggested that other variants may confer risk. Several candidate alleles have been identified in addition to those found in African American families in the initial report by Ewing et al. ${ }^{36}$ For instance, Lin and colleagues $^{51}$ studied a cohort of Chinese men and reported that the G84E mutation was not found in their study population. However, a G135E mutation was found twice in 575 cases but not in any of 1,536 controls, a significant difference
$(P=0.027)$. However, further epidemiological evidence is required to establish a role for these variants.

A consensus is emerging that $H O X B 13$ is a critical player in PC risk. But the mutation is generally rare in most populations. The gene may be more relevant for northern European populations, as well as in individuals with strong family history or early disease onset. Though the gene's epidemiological role is becoming clearer, the mechanism by which the G84E allele confers risk remains a crucial question.

\section{The homeobox gene family}

$H O X B 13$ is a member of the homeobox $(H O X)$ gene family, which is a large group of clustered, paralogous transcription factors that are crucial for embryonic development along the anterior-posterior axis. ${ }^{52}$ HOX genes are defined by a characteristic 180-base sequence called the homeobox, which encodes a helix-turn-helix protein motif that mediates binding to enhancer DNA sequences. ${ }^{52} \mathrm{HOX}$ genes are further distinguished by collinearity, an incompletely understood phenomenon in which genes in an $\mathrm{HOX}$ cluster are sequentially expressed along the anteroposterior axis, ie, upstream genes are expressed in anterior segments, and downstream genes are expressed in posterior segments (see Figure 1). ${ }^{52}$

\section{Function of HOX genes}

$H O X$ genes play many roles in both embryonic development and differentiated tissues. Much of this functional diversity is explained by the large size of the $H O X$ gene family, tightly regulated spatial and temporal expression patterns, and slight

A

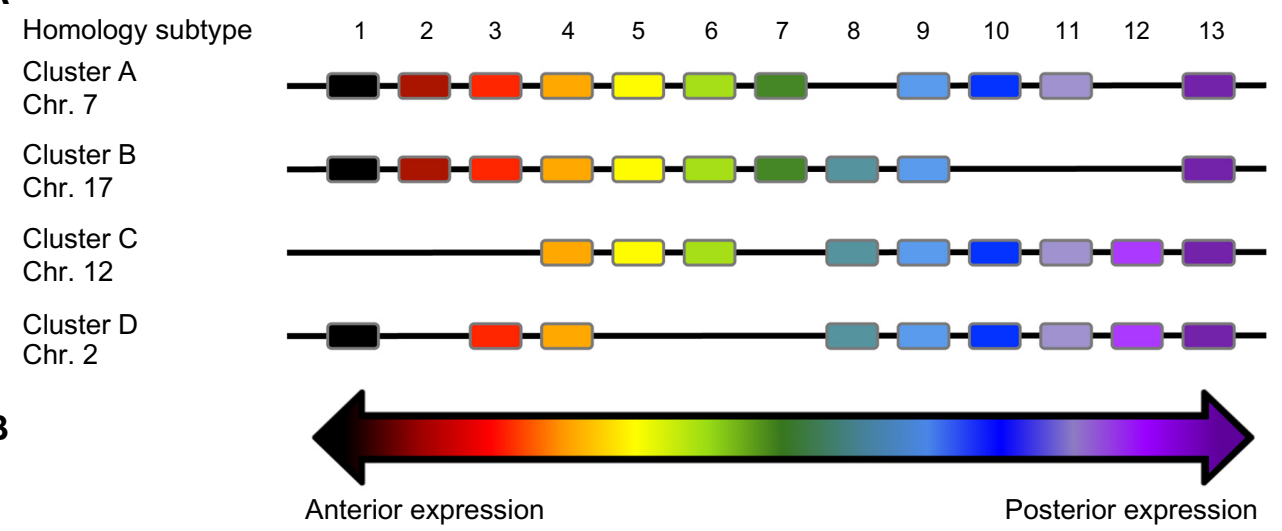

Figure I The genomic architecture of HOX genes and schematic of gene expression in embryonic development.

Notes: (A) Humans have four clusters of HOX genes on different chromosomes, labeled Cluster A through Cluster D. Each cluster comprises a variable subset of the 13 homology-based HOX gene subtypes. The relative order of the subtypes is preserved across clusters. This conserved ordering is attributed to the genomic duplicationbased mechanism by which the clusters arose. (B) During embryonic development, HOX genes are expressed sequentially in partially overlapping zones along the anteriorposterior axis, a phenomenon called collinearity. Accordingly, HOXI3 paralogs, including HOXBI3, are expressed in posterior regions of the embryo and direct development of the spinal cord, digestive tract, and urogenital system.

Abbreviation: HOX, homeobox gene. 
variations in homeodomain sequences that result in specificity for different enhancer DNA sequences. ${ }^{52}$ The number of $H O X$ genes, as well as the number of $H O X$ gene clusters, varies widely across phyla. ${ }^{53}$ Genomic amplification and evolutionary divergence have yielded paralogous $H O X$ gene homology subtypes that are defined by sequence similarity of the homeobox sequence. ${ }^{53}$ In addition, larger genomic events have led to amplification of entire $H O X$ gene clusters, whereas subsequent losses have resulted in clusters that contain only a subset of the homology subtypes. ${ }^{53}$ Together, the increase in number of genes and clusters allows $\mathrm{HOX}$ genes to play many diverse roles. In spite of this variability, the fundamental mechanism of $H O X$-mediated anterior-posterior patterning is highly conserved across species, which manifests in vertebrates as typical clustered genomic architecture and collinear pattern of expression, but most importantly as extensive coding sequence homology, especially of the characteristic homeobox domain. ${ }^{52}$

\section{Organization of human HOX genes}

Like all tetrapods, humans have four HOX clusters, labeled A-D. Each cluster consists of 9-11 genes that are a subset of the $13 \mathrm{HOX}$ subtypes (Figure 1A). All four clusters have a $H O X 13$ paralog, and these genes are the furthest downstream constituents of each cluster. As predicted by the collinearity principle of $H O X$ genes, $H O X 13$ paralogs are expressed in the most posterior segments of the developing embryo. In 1996, Zeltser et al ${ }^{54}$ identified a novel gene about $70 \mathrm{~kb}$ downstream of the other known $H O X B$ cluster constituents on chromosome 17. Due to high homeodomain sequence identity with $H O X 13$ paralogs A, C, and D, it was dubbed $H O X B 13 .{ }^{54}$ In accordance with the principle of collinearity, this downstream position yields $H O X B 13$ expression in posterior structures, where it plays a role in the development of the spinal cord, digestive tract, and urogenital system, including the prostate..$^{54,55}$

\section{Role of HOXB / 3}

Early studies in mice clarified the role of $H O X B 13$ in normal development and tissue function. Sreenath, et $\mathrm{al}^{55}$ used Northern blotting and in situ hybridization to confirm that murine $H O X B 13$ is expressed during posterior segment development. By sampling these tissues at multiple developmental time points, they found that the $\mathrm{HOXB13}$ transcript appears early in posterior organogenesis, and that expression persists into adulthood in distal colon tissues, as well as in an androgen-independent manner in all four lobes of the murine prostate. ${ }^{55}$ Murine knockout studies conducted by Economides and Capecchi ${ }^{56}$ demonstrated that the $H O X 13$ paralogs $H O X B 13$ and $H O X D 13$ apparently cooperate in normal prostate development, as double-knockout mice had malformed ducts with severe truncations and branching defects. However, mice homozygous for homeobox domaindamaging mutations in $H O X B 13$ exhibited multiple structural and functional defects of the secretory cells in the murine ventral prostate, suggesting that $H O X B 13$ is the crucial mediator of terminal differentiation in these cells. ${ }^{56}$ Examination of seminal fluid from knockout mice showed no evidence of characteristic ventral prostate secretory proteins such as the kazal-type protease inhibitor p12 or the spermine binding protein p25. ${ }^{56}$ Furthermore, histopathological examination of the ducts revealed cuboid rather than the normal columnar epithelial cell morphology, accompanied by loss of polarity evidenced by CD44 expression; both of these features are consistent with precancerous and neoplastic lesions. ${ }^{56}$

Additional explorations have built on these basic clues about the gene's biological role, and mounting evidence suggests that the gene might play a complex-but-plausible role in the carcinogenesis of prostate tumors. The earliest studies focused on the role of $H O X B 13$ in growth regulation via androgen receptor (AR) signaling or cell cycle regulation, but more-recent studies have highlighted many additional roles in PC oncogenesis. However, the picture remains clouded by incongruous results.

\section{HOXBI3 and prostate cancer}

Overexpression and knockdown studies in PC cell lines have suggested that $H O X B 13$ functions in both normal adult tissue and prostate cancer through the AR, but conflicting findings make it difficult to dissect its physiological role. Jung et $\mathrm{al}^{57}$ showed that $H O X B 13$ was expressed only in cells that also expressed the AR. In their experiments, overexpression of the gene inhibited growth of PC cell lines, which was associated with a dose-dependent disruption of stimulatory AR signaling, as assayed by expression of downstream reporter genes. ${ }^{57}$ In contrast, Norris et $\mathrm{al}^{58}$ found that $H O X B 13$ knockdown via RNA interference inhibited prostate cellline growth. Under $H O X B 13$ knockdown conditions, they observed repressed transcription of some androgen-regulated genes, but found that $H O X B 13$ acted as an obligate coactivator for expression of others by modulating recruitment of AR and other coregulators to target sequences. ${ }^{58}$ These authors used a yeast two-hybrid assay and fluorescence resonance energy transfer to confirm that the homeodomain of $H O X B 13$ physically interacts with the AR. ${ }^{58}$ Intriguingly, Kim et al ${ }^{59}$ observed that in the setting of AR expression, the $H O X B 13$ 
transcript repressed the cell cycle, whereas $H O X B 13$ exerted a stimulatory effect on the cell cycle when AR was absent. Indeed, in AR-negative cells, increased $H O X B 13$ expression promoted growth via inhibition of the tumor suppressor $\mathrm{p} 21$ and resultant activation of RB-E2F signaling. ${ }^{59}$ The authors speculated that this role for $H O X B 13$ may help explain persistent growth of androgen-independent tumors. ${ }^{59}$ These findings may also shed light on the conflicting results of expression studies. One possibility is that heterogeneity between PC cell lines results in context-specific response to $H O X B 13$ perturbations, as noted in the presence versus absence of the AR.

In addition, $H O X B 13$, like other $H O X$ genes in other tissues, has been linked to cell-cycle regulation pathways that are important in PC. Jung et $\mathrm{al}^{60}$ found that overexpressed $H O X B 13$ in PC cell lines inhibited the transcription factor T-cell factor 4 . Removal of this pro-cell division signal induced arrested growth at the G1 phase due to suppressed expression of the key cell-cycle regulators cyclin D1 and c-myc. ${ }^{60}$ Building on these results, Hamid et $\mathrm{al}^{61}$ explored the effects of $H O X B 13$ overexpression and knockdown on the cell cycle. They also noted overexpression-induced arrest at the G1 phase and associated ubiquitination and degradation of cyclin D1, as well as decreased activation of the stimulatory RB protein. ${ }^{61}$ In contrast, knockdown resulted in upregulation of cyclins, increased activation of RB, and more-rapid cell growth. ${ }^{61}$

HOXB13 has been tied to PC biology in several other ways. McMullin et al, ${ }^{62}$ for example, showed that the expression of $H O X B 13$ itself is regulated by FOXA1, a transcription factor with prostate-specific effects on expression that has been tied to many aspects of prostate biology and tumor development. The gene has also been linked to PC risk loci identified in genome-wide association studies. For instance, Huang and $\mathrm{Cai}^{63}$ recently found that the risk allele for rs339331 at chromosome 6q22 enhances the binding of HOXB13, AR, and FOXA1 to the promoter for the RFX6 gene, which stimulates tumor progression and aggressiveness. Since $H O X B 13$ plays many roles in adult prostate tumors, it is likely that it interacts with additional risk loci. It is furthermore probable that the HOXB13 G84E risk allele modulates these interactions, although these effects have not yet been rigorously investigated.

Epigenetic modifications that alter $H O X B 13$ expression may also be important in PC. In AR-negative tumor cell lines, Ren et $\mathrm{al}^{64}$ found that histone modifications prevented expression of $H O X B 13$. In these cells, transcription factor YY1 recruited the suppressive histone deacetylase HDAC4 to the $H O X B 13$ promoter. ${ }^{64}$ However, administration of the histone deacetylase inhibitor sodium butyrate suppressed repressive histone modifications and resulted in a dramatic increase in $H O X B 13$ and concomitant inhibition of cell proliferation. ${ }^{64}$ Liu et $\mathrm{al}^{65}$ noted a similar effect in which all-trans retinoic acid increased $H O X B 13$ expression and decreased cell growth via histone methylation modifications mediated by EZH2 and DNMT3b.

$H O X B 13$ may be involved in castration resistance and metastasis of PC, as well. In another study of androgen-independent prostate cell lines, the gene potently stimulated tumor invasion and metastasis by decreasing intracellular zinc concentrations, and resulted in increased nuclear factor- $\kappa \mathrm{B}$ signaling. ${ }^{66}$

Due to these many roles in prostate tumor biology, $H O X B 13$ expression has been suggested as a biomarker for PC diagnosis or detection of recurrence. In microarray studies, Edwards et $\mathrm{al}^{67}$ found that the gene is ubiquitously expressed in the human prostate but significantly overexpressed in prostate tumor tissue versus normal prostate and noncancerous samples from other lineages. This differential expression was confirmed via reverse-transcription polymerase chain reaction in 37 primary prostate tumor specimens versus 16 adjacent normal samples plus four subjects without evidence of malignancy. ${ }^{67} \mathrm{Kim}$ and colleagues also detected overexpression, but only in castration-resistant tumors. ${ }^{59}$ In an explicit evaluation of $H O X B 13$ as a PC biomarker in 57 human $\mathrm{PC}$ tumors, Jeong et $\mathrm{al}^{68}$ saw a positive correlation between expression and Gleason grade, as well as with preoperative prostate-specific antigen measurements. Furthermore, four subjects with tumors refractory to androgen deprivation had very high expression of the gene. ${ }^{68}$ All of these results have led to speculation that $H O X B 13$ or other related markers might have utility in screening or diagnostic testing.

\section{$H O X B I 3$ in other tumors}

Reports of $H O X B 13$ function in malignancies of other tissues are similarly contradictory. Because expression of the gene is maintained in the adult distal colon, it is perhaps unsurprising that the gene has been implicated in colon cancer. In colorectal cell lines, $H O X B 13$ expression seems to inhibit growth by some of the same mechanisms observed in prostate tumors, namely suppression of TCF4 and $c-m y c$ expression. ${ }^{69}$ The gene may similarly act as a tumor suppressor in renal cell carcinoma. ${ }^{70}$ However, although the gene has been investigated in tumors of the endometrium, ovaries, cervix, and breast, its role in these malignancies is less clear. ${ }^{70-73}$ In breast cancer cell lines, for example, $\mathrm{Ma}$ et $\mathrm{al}^{74}$ noted that 
ectopic expression of $H O X B 13$ promoted tumor cell motility and invasion. Furthermore, the ratio of $H O X B 13: I L 17 B R$ expression predicted clinical response to tamoxifen, and a subsequent study found that $H O X B 13$ causes tamoxifen resistance via modulation of ER $\alpha$ and IL-6 expression. ${ }^{74-76}$

\section{The role of HOXB/3 G84E in prostate cancer risk}

The HOXB13 G84E variant, as well as other, rarer potential risk alleles in the gene, are computationally predicted to impair the structure or function of the encoded protein. The variants fall in domains that are highly conserved across species. ${ }^{36}$ The G84E variant lies in a domain that binds MEIS proteins, which are critical coactivators of $H O X$ gene binding that modulate target specificity and downstream expression. ${ }^{77}$ Other, less-proven potential risk alleles, including two found only in patients of African descent, lie in the highly conserved homeobox domain. ${ }^{36}$

It is difficult to fully assess the mechanistic underpinnings of PC risk variants in $H O X B 13$, because it is not even certain whether the gene acts as a tumor suppressor or oncogene. These contradictory results may be attributable to context-specific roles for $H O X B 13$, including the polar opposite effects of $\mathrm{HOXB13}$ on the cell cycle in the presence versus the absence of the AR, as noted by Kim et al. ${ }^{59}$ The original report on G84E noted the conflicts in the literature and suggested that the variant may induce a gain of function, since both inherited and acquired truncating mutations are absent. ${ }^{36}$ However, inherited truncating mutations may not be evolutionarily tolerated due to the critical role of $H O X B 13$ in embryonic development. Furthermore, some other cancer risk genes, including $B R C A 1$, are not commonly somatically mutated.

It is clear that the $H O X B 13$ gene plays a complex and crucial role in many pathways implicated in PC oncogenesis, progression, and metastasis. HOXB13 is preferentially recruited to the risk allele of an established $\mathrm{PC}$-associated SNP, enhancing expression of $R F X 6$, which is a driver of prostate cancer cell migration and a predictor of disease progression. ${ }^{63}$ To better understand the role of the gene in PC risk, future research must clarify its role in normal prostate tissue, as well as AR-positive and AR-negative cancer cell lines. Only then will we be able to piece together the gene's wide-ranging roles in androgen receptor signaling, cell-cycle regulation, and castration-resistant disease. Finally, studies of $H O X B 13$ function in cell lines with and without the G84E variant will enhance our understanding of PC oncogenesis and progression.

\section{Acknowledgments}

We gratefully acknowledge the many men who have participated in the cited studies by providing DNA samples, tumor tissue, and medical information. We also express our gratitude to the Intramural Program of the National Human Genome Research Institute of the National Institutes of Health (EAO and BD) and to the National Institutes of Health Oxford Cambridge Graduate Scholars Program (BD).

\section{Disclosure}

The authors report no conflicts of interest in this work.

\section{References}

1. Siegel R, Naishadham D, Jemal A. Cancer statistics, 2013. CA Cancer J Clin. 2013;63(1):11-30.

2. Grönberg H, Damber L, Damber JE. Studies of genetic factors in prostate cancer in a twin population. J Urol. 1994;152(5 Pt 1):1484-1487; discussion 1487-1489.

3. Lichtenstein P, Holm NV, Verkasalo PK, et al. Environmental and heritable factors in the causation of cancer - analyses of cohorts of twins from Sweden, Denmark, and Finland. N Engl J Med. 2000;343(2):78-85.

4. Verkasalo PK, Kaprio J, Koskenvuo M, Pukkala E. Genetic predisposition, environment and cancer incidence: a nationwide twin study in Finland, 1976-1995. Int J Cancer. 1999;83(6):743-749.

5. Carter BS, Beaty TH, Steinberg GD, Childs B, Walsh PC. Mendelian inheritance of familial prostate cancer. Proc Natl Acad Sci U S A. 1992;89(8):3367-3371.

6. Conlon EM, Goode EL, Gibbs M, et al. Oligogenic segregation analysis of hereditary prostate cancer pedigrees: evidence for multiple loci affecting age at onset. Int J Cancer. 2003;105(5):630-635.

7. Gong G, Oakley-Girvan I, Wu AH, et al. Segregation analysis of prostate cancer in 1,719 white, African-American and Asian-American families in the United States and Canada. Cancer Causes Control. 2002;13(5): 471-482.

8. Grönberg H, Damber L, Damber JE, Iselius L. Segregation analysis of prostate cancer in Sweden: support for dominant inheritance. Am J Epidemiol. 1997;146(7):552-557.

9. MacInnis RJ, Antoniou AC, Eeles RA, et al. Prostate cancer segregation analyses using 4390 families from UK and Australian population-based studies. Genet Epidemiol. 2010;34(1):42-50.

10. Pakkanen S, Baffoe-Bonnie AB, Matikainen MP, et al. Segregation analysis of 1,546 prostate cancer families in Finland shows recessive inheritance. Hum Genet. 2007;121(2):257-267.

11. Risch N. The genetic epidemiology of cancer: interpreting family and twin studies and their implications for molecular genetic approaches. Cancer Epidemiol Biomarkers Prev. 2001;10(7):733-741.

12. Easton DF, Schaid DJ, Whittemore AS, Isaacs WJ; International Consortium for Prostate Cancer Genetics. Where are the prostate cancer genes? - A summary of eight genome wide searches. Prostate. 2003;57(4):261-269.

13. Foulkes WD. Inherited susceptibility to common cancers. $N$ Engl $J$ Med. 2008;359(20):2143-2153.

14. Langeberg WJ, Isaacs WB, Stanford JL. Genetic etiology of hereditary prostate cancer. Front Biosci. 2007;12:4101-4110.

15. Nupponen NN, Carpten JD. Prostate cancer susceptibility genes: many studies, many results, no answers. Cancer Metastasis Rev. 2001; 20(3-4):155-164.

16. Ostrander EA, Markianos K, Stanford JL. Finding prostate cancer susceptibility genes. Annu Rev Genomics Hum Genet. 2004;5: $151-175$. 
17. Pomerantz MM, Freedman ML. Genetics of prostate cancer risk. Mt Sinai J Med. 2010;77(6):643-654.

18. Verhage BA, Kiemeney LA. Inherited predisposition to prostate cancer. Eur J Epidemiol. 2003;18(11):1027-1036.

19. Eeles RA, Kote-Jarai Z, Al Olama AA, et al; UK Genetic Prostate Cancer Study Collaborators/British Association of Urological Surgeons' Section of Oncology; UK ProtecT Study Collaborators; PRACTICAL Consortium. Identification of seven new prostate cancer susceptibility loci through a genome-wide association study. Nat Genet. 2009;41(10):1116-1121.

20. Eeles RA, Kote-Jarai Z, Giles GG, et al; UK Genetic Prostate Cancer Study Collaborators; British Association of Urological Surgeons' Section of Oncology; UK ProtecT Study Collaborators. Multiple newly identified loci associated with prostate cancer susceptibility. Nat Genet. 2008;40(3):316-321.

21. Eeles RA, Olama AA, Benlloch S, et al; COGS-Cancer Research UK GWAS-ELLIPSE (part of GAME-ON) Initiative; Australian Prostate Cancer Bioresource; UK Genetic Prostate Cancer Study Collaborators/British Association of Urological Surgeons' Section of Oncology; UK ProtecT (Prostate testing for cancer and Treatment) Study Collaborators; PRACTICAL (Prostate Cancer Association Group to Investigate Cancer-Associated Alterations in the Genome) Consortium. Identification of 23 new prostate cancer susceptibility loci using the iCOGS custom genotyping array. Nat Genet. 2013;45(4):385-391, 391e1.

22. Kote-Jarai Z, Easton DF, Stanford JL, et al; PRACTICAL Consortium. Multiple novel prostate cancer predisposition loci confirmed by an international study: the PRACTICAL Consortium. Cancer Epidemiol Biomarkers Prev. 2008;17(8):2052-2061.

23. Kote-Jarai Z, Olama AA, Giles GG, et al. Seven prostate cancer susceptibility loci identified by a multi-stage genome-wide association study. Nat Genet. 2011;43(8):785-791.

24. Kote-Jarai Z, Saunders EJ, Leongamornlert DA, et al; COGS-CRUK GWAS-ELLIPSE (Part of GAME-ON) Initiative; UK Genetic Prostate Cancer Study Collaborators/British Association of Urological Surgeons' Section of Oncology; UK ProtecT Study Collaborators; PRACTICAL Consortium. Fine-mapping identifies multiple prostate cancer risk loci at $5 \mathrm{p} 15$, one of which associates with TERT expression. Hum Mol Genet. 2013;22(12):2520-2528.

25. Lu L, Cancel-Tassin G, Valeri A, et al; International Consortium for Prostate Cancer Genetics. Chromosomes 4 and 8 implicated in a genome wide SNP linkage scan of 762 prostate cancer families collected by the ICPCG. Prostate. 2012;72(4):410-426.

26. Jin G, Lu L, Cooney KA, et al; International Consortium for Prostate Cancer Genetics. Validation of prostate cancer risk-related loci identified from genome-wide association studies using family-based association analysis: evidence from the International Consortium for Prostate Cancer Genetics (ICPCG). Hum Genet. 2012;131(7): $1095-1103$.

27. Teerlink CC, Thibodeau SN, McDonnell SK, et al; International Consortium for Prostate Cancer Genetics. Association analysis of 9,560 prostate cancer cases from the International Consortium of Prostate Cancer Genetics confirms the role of reported prostate cancer associated SNPs for familial disease. Hum Genet. 2014;133(3): 347-356.

28. Lange EM, Ho LA, Beebe-Dimmer JL, et al. Genome-wide linkage scan for prostate cancer susceptibility genes in men with aggressive disease: significant evidence for linkage at chromosome $15 \mathrm{q} 12$. Hum Genet. 2006;119(4):400-407.

29. Schaid DJ, McDonnell SK, Zarfas KE, et al; Investigators of the International Consortium for Prostate Cancer Genetics. Pooled genome linkage scan of aggressive prostate cancer: results from the International Consortium for Prostate Cancer Genetics. Hum Genet. 2006;120(4):471-485.

30. Slager SL, Schaid DJ, Cunningham JM, et al. Confirmation of linkage of prostate cancer aggressiveness with chromosome 19q. Am J Hum Genet. 2003;72(3):759-762.
31. Slager SL, Zarfas KE, Brown WM, et al. Genome-wide linkage scan for prostate cancer aggressiveness loci using families from the University of Michigan Prostate Cancer Genetics Project. Prostate. 2006;66(2): 173-179.

32. Stanford JL, McDonnell SK, Friedrichsen DM, et al. Prostate cancer and genetic susceptibility: a genome scan incorporating disease aggressiveness. Prostate. 2006;66(3):317-325.

33. Goddard KA, Witte JS, Suarez BK, Catalona WJ, Olson JM. Model-free linkage analysis with covariates confirms linkage of prostate cancer to chromosomes 1 and 4. Am J Hum Genet. 2001;68(5):1197-1206.

34. Schaid DJ, Stanford JL, McDonnell SK, et al. Genome-wide linkage scan of prostate cancer Gleason score and confirmation of chromosome 19q. Hum Genet. 2007;121(6):729-735.

35. Witte JS, Goddard KA, Conti DV, et al. Genomewide scan for prostate cancer-aggressiveness loci. Am J Hum Genet. 2000;67(1):92-99.

36. Ewing CM, Ray AM, Lange EM, et al. Germline mutations in HOXB13 and prostate-cancer risk. N Eng J Med. 2012;366(2):141-149.

37. Lange EM, Gillanders EM, Davis CC, et al. Genome-wide scan for prostate cancer susceptibility genes using families from the University of Michigan prostate cancer genetics project finds evidence for linkage on chromosome 17 near BRCA1. Prostate. 2003;57(4):326-334.

38. Penney KL, Salinas CA, Pomerantz M, et al. Evaluation of 8q24 and $17 \mathrm{q}$ risk loci and prostate cancer mortality. Clin Cancer Res. 2009;15(9): 3223-3230.

39. Gillanders EM, Xu J, Chang BL, et al. Combined genome-wide scan for prostate cancer susceptibility genes. J Natl Cancer Inst. 2004;96(16): $1240-1247$.

40. Xu J, Dimitrov L, Chang BL, et al; ACTANE Consortium. A combined genomewide linkage scan of 1,233 families for prostate cancersusceptibility genes conducted by the international consortium for prostate cancer genetics. Am J Hum Genet. 2005;77(2):219-229.

41. Lange EM, Robbins CM, Gillanders EM, et al. Fine-mapping the putative chromosome 17q21-22 prostate cancer susceptibility gene to a $10 \mathrm{cM}$ region based on linkage analysis. Hum Genet. 2007;121(1):49-55.

42. Lange EM, Chen H, Brierley K, et al. Linkage analysis of 153 prostate cancer families over a $30-\mathrm{cM}$ region containing the putative susceptibility locus HPCX. Clin Cancer Res. 1999;5(12):4013-4020.

43. Stott-Miller M, Karyadi DM, Smith T, et al. HOXB13 mutations in a population-based, case-control study of prostate cancer. Prostate. 2013;73(6):634-641.

44. Witte JS, Mefford J, Plummer SJ, et al. HOXB13 mutation and prostate cancer: studies of siblings and aggressive disease. Cancer Epidemiol Biomarkers Prev. 2013;22(4):675-680.

45. Breyer JP, Avritt TG, McReynolds KM, Dupont WD, Smith JR. Confirmation of the HOXB13 G84E germline mutation in familial prostate cancer. Cancer Epidemiol Biomarkers Prev. 2012;21(8):1348-1353.

46. Xu J, Lange EM, Lu L, et al; International Consortium for Prostate Cancer Genetics. HOXB13 is a susceptibility gene for prostate cancer: results from the International Consortium for Prostate Cancer Genetics (ICPCG). Hum Genet. 2013;132(1):5-14.

47. MacInnis RJ, Severi G, Baglietto L, et al. Population-based estimate of prostate cancer risk for carriers of the HOXB13 missense mutation G84E. PLoS One. 2013;8(2):e54727.

48. Karlsson R, Aly M, Clements M, et al. A population-based assessment of germline HOXB13 G84E mutation and prostate cancer risk. Eur Urol. 2014;65(1):169-176.

49. Schroeck FR, Zuhlke KA, Siddiqui J, Siddiqui R, Cooney KA, Wei JT. Testing for the recurrent HOXB13 G84E germline mutation in men with clinical indications for prostate biopsy. J Urol. 2013;189(3): 849-853.

50. Chen Z, Greenwood C, Isaacs WB, et al. The G84E mutation of HOXB13 is associated with increased risk for prostate cancer: results from the REDUCE trial. Carcinogenesis. 2013;34(6):1260-1264.

51. Lin X, Qu L, Chen Z, et al. A novel germline mutation in HOXB13 is associated with prostate cancer risk in Chinese men. Prostate. 2013;73(2):169-175. 
52. McGinnis W, Krumlauf R. Homeobox genes and axial patterning. Cell. 1992;68(2):283-302.

53. Garcia-Fernàndez $\mathrm{J}$. The genesis and evolution of homeobox gene clusters. Nat Rev Genet. 2005;6(12):881-892.

54. Zeltser L, Desplan C, Heintz N. Hoxb-13: A new Hox gene in a distant region of the HOXB cluster maintains colinearity. Development. 1966;122(8):2475-2484.

55. Sreenath T, Orosz A, Fujita K, Bieberich CJ. Androgen-independent expression of hoxb-13 in the mouse prostate. Prostate. 1999;41(3): 203-207.

56. Economides KD, Capecchi MR. Hoxb13 is required for normal differentiation and secretory function of the ventral prostate. Development. 2003;130(10):2061-2069.

57. Jung C, Kim RS, Zhang HJ, Lee SJ, Jeng MH. HOXB13 induces growth suppression of prostate cancer cells as a repressor of hormone-activated androgen receptor signaling. Cancer Res. 2004;64(24):9185-9192.

58. Norris JD, Chang CY, Wittmann BM, et al. The homeodomain protein HOXB13 regulates the cellular response to androgens. Mol Cell. 2009;36(3):405-416.

59. Kim SD, Park RY, Kim YR, et al. HOXB13 is co-localized with androgen receptor to suppress androgen-stimulated prostate-specific antigen expression. Anat Cell Biol. 2010;43(4):284-293.

60. Jung C, Kim RS, Lee SJ, Wang C, Jeng MH. HOXB13 homeodomain protein suppresses the growth of prostate cancer cells by the negative regulation of T-cell factor 4. Cancer Res. 2004;64(9):3046-3051.

61. Hamid SM, Cicek S, Karamil S, et al. HOXB13 contributes to G1/S and $\mathrm{G} 2 / \mathrm{M}$ checkpoint controls in prostate. Mol Cell Endocrinol. 2014;383(1-2):38-47.

62. McMullin RP, Dobi A, Mutton LN, et al. A FOXA1-binding enhancer regulates Hoxb13 expression in the prostate gland. Proc Natl Acad Sci U S A. 2010;107(1):98-103.

63. Huang H, Cai B. G84E mutation in HOXB13 is firmly associated with prostate cancer risk: a meta-analysis. Tumour Biol. 2014;35(2): $1177-1182$.

64. Ren B, Yu G, Tseng GC, et al. MCM7 amplification and overexpression are associated with prostate cancer progression. Oncogene. 2006;25(7): 1090-1098.
65. Liu Z, Ren G, Shangguan C, et al. ATRA inhibits the proliferation of DU145 prostate cancer cells through reducing the methylation level of HOXB13 gene. PLoS One. 2012;7(7):e40943.

66. Kim YR, Kim IJ, Kang TW, et al. HOXB13 downregulates intracellular zinc and increases NF- $\mathrm{KB}$ signaling to promote prostate cancer metastasis. Oncogene. Epub October 7, 2013.

67. Edwards S, Campbell C, Flohr P, et al. Expression analysis onto microarrays of randomly selected cDNA clones highlights HOXB13 as a marker of human prostate cancer. Br J Cancer. 2005;92(2):376-381.

68. Jeong TO, Oh KJ, Xuan Nguyen NT, et al. Evaluation of HOXB13 as a molecular marker of recurrent prostate cancer. Mol Med Rep. 2012;5(4):901-904.

69. Jung C, Kim RS, Zhang H, et al. HOXB13 is downregulated in colorectal cancer to confer TCF4-mediated transactivation. Br JCancer 2005;92(12):2233-2239.

70. Okuda H, Toyota M, Ishida W, et al. Epigenetic inactivation of the candidate tumor suppressor gene HOXB13 in human renal cell carcinoma. Oncogene. 2006;25(12):1733-1742.

71. Yamashita T, Tazawa S, Yawei Z, et al. Suppression of invasive characteristics by antisense introduction of overexpressed HOX genes in ovarian cancer cells. Int J Oncol. 2006;28(4):931-938.

72. Miao J, Wang Z, Provencher H, et al. HOXB13 promotes ovarian cancer progression. Proc Natl Acad Sci U S A. 2007;104(43):17093-17098.

73. López R, Garrido E, Piña P, et al. HOXB homeobox gene expression in cervical carcinoma. Int J Gynecol Cancer. 2006;16(1):329-335.

74. Ma XJ, Wang Z, Ryan PD, et al. A two-gene expression ratio predicts clinical outcome in breast cancer patients treated with tamoxifen. Cancer Cell. 2004;5(6):607-616.

75. Jerevall PL, Brommesson S, Strand C, et al. Exploring the two-gene ratio in breast cancer - independent roles for HOXB13 and IL17BR in prediction of clinical outcome. Breast Cancer Res Treat. 2008;107(2): 225-234.

76. Shah N, Jin K, Cruz LA, et al. HOXB13 mediates tamoxifen resistance and invasiveness in human breast cancer by suppressing ER $\alpha$ and inducing IL-6 expression. Cancer Res. 2013;73(17):5449-5458.

77. Williams TM, Williams ME, Innis JW. Range of HOX/TALE superclass associations and protein domain requirements for HOXA13:MEIS interaction. Dev Biol. 2005;277(2):457-471.
Pharmacogenomics and Personalized Medicine

\section{Publish your work in this journal}

Pharmacogenomics and Personalized Medicine is an international, peerreviewed, open access journal characterizing the influence of genotype on pharmacology leading to the development of personalized treatment programs and individualized drug selection for improved safety, efficacy and sustainability. This journal is indexed on the American Chemical

\section{Dovepress}

Society's Chemical Abstracts Service (CAS). The manuscript management system is completely online and includes a very quick and fair peer-review system, which is all easy to use. Visit http://www.dovepress. com/testimonials.php to read real quotes from published authors. 